\title{
Morphometric Characterization of Yamuna River basin around Agra, Firozabad and Etawah Districts, Uttar Pradesh, using Remote Sensing and GIS Techniques
}

\author{
Liaqat A.K. Rao' ${ }^{1}$ Armugha Khan ${ }^{1}$, Himanshu Govil ${ }^{2}$ \\ Department of Geology, Aligarh Muslim University, Aligarh ${ }^{1}$ \\ Department of Applied Geology, National Institute of Technology, Raipur ${ }^{2}$
}

\begin{abstract}
The present study is carried out to characterize the morphometry of Yamuna River basin using remote sensing and GIS techniques, covering parts of Agra, Firozabad and Etawah districts of Uttar Pradesh. The morphometric parameters were calculated and specialized through spatial analysis of GIS. The results of the morphometric parameters are the variables of linear, areal and relief aspects. The integrated analysis of the variables concludes that the basin is elongated in shape, having highly permeable rocks and suffered severe ravenous erosion. Hypsometric analysis shows that the basin is in mature to old stage of geomorphic development.
\end{abstract}

Keywords: Yamuna River, GIS, Morphometry, ravenous.

\section{INTRODUCTION}

Morphmetric analysis characterizes the geometric and compositional aspects of environmental system, serve as indicators of the related form, structural arrangement and interaction between aspects and network of fluvial channel in a basin [1]. The morphometric studies have played a vital role in hydro geological studies in order to understand the occurrence, distribution and movement of water, geology and structure of the basin.

In geomorphologic studies morphometric analysis of drainage network constitute active morphogenetic processes in the composition of terrestrial landscape. The quantitative analysis of morphometric parameters is of immense value particularly in the development and prioritization of the conservation of soil and water in the watershed [2].

The remote sensing data associated with GIS has prove to be a powerful tool in the morphometric analysis of the watersheds of river basin [3], [4] and [5]. The use of SRTM data and GIS technique shows precision, fast and inexpensive to calculate morphometric parameters [6], [7], [8] and [9]. The present study is carried out to analyse various morphometric attributes of Yamuna river basin in and around Agra, Firozabad and Etawah districts of Uttar Pradesh. The present study is aimed to carry out detailed work on the morphometric and hypsometry of the area of interest.

\section{STUDY AREA}

The study area (Fig-1) is located between $27^{\circ} 11^{\prime}$ degree latitude North and $78^{\circ} .0^{\prime}$ degree to $78^{\circ} .2^{\prime}$ degree longitudes East and falling in the SOI toposheets no.541/3, 541/4, 541/7 and 541/8, covering an area of about $2975 \mathrm{~km}^{2}$. Physiographically, the area is divided into southern and western stretches confined by the Yamuna River and ravines which further divided into Khadar lowland, Trans Yamuna plain, Yamuna upland and Yamuna-Chambal ravines. The climate is semi-arid with an average rainfall of $752.26 \mathrm{~mm}$.

\section{GEOLOGY}

Geologically the area is underlain by the rocks belonging to the upper Bhander series of the Upper Vindhyan Supergroup. The alluvium consists of interbedded deposits of sand, silt and clays. At places calcareous concretions are also found associated with alluvium. The upper Bhander sandstone is covered by thick alluvium of Quaternary age and constitute medium to fine grained, purplish to reddish spotted and laminated with intercalations of shale, pebbles, conglomerate, siltstone and grit.

The geological sequence of the area is as follows- 


\section{MATERIAL AND METHODS}

Drainage map (Fig-1.1) and split drainage map of three sub watersheds (Fig-1.2, 1.3, 1.4) of the study area have been prepared using Survey of India toposheets on 1:50000 scale and further validated by Landsat-8 data. The morphometric parameters of all sub-watersheds have been determined using GIS software's, ArcGIS 10.1 and Arc Hydro tool for delineating, digitizing and calculating the watersheds, drainage features and drainage parameters. The methodology for computation of morphometric parameters is given in Table (1). Digital elevation model (DEM) of the different subwatersheds (Fig-1.5, 1.6, 1.7) are also prepared using SRTM 30 meter resolution data (Freely available at USGS Earth Explorer) used for hypsometric analysis and for visual study. Hypsometric curves have been drawn using Micro-DEM tool which geared for geological applications with digital elevation models (DEMs).

\section{RESULTS AND DISCUSSION}

The morphometric analyses in parts of Yamuna River basin have been carried out using remote sensing and GIS techniques. The area shows dendritic drainage pattern forming dense and irregular network of stream joining main stream at less than right angle indicates uniform lithology. Based on the drainage pattern the Yamuna River basin is subdivided into three sub-watersheds covering an area of about $2975 \mathrm{~km}^{2}$ in parts of Agra, Firozabad, and Etawah district. The result of linear areal and relief parameters and drainage characteristics of the sub-watersheds are given in Table [(1.1 (a), (b), (c), (1.2), (1.3) and (1.4)] and briefly discussed as follows-

\section{LINEAR ASPECTS:-}

The linear aspects include stream length, mean stream length, stream length ratio and bifurcation ratio. The results of this analysis are given in Table [(1.1 (a), (b), (c)] and discussed as;

(1) Stream order (Lu)

The first step in drainage basin analysis is the stream segment and assignment of stream orders which express the hierarchical relationship between the segments and it is fundamental property of stream network as it relates to the relative discharge of a channel segment. [10] method is used in present study for hierarchical rank of the stream order. The present study shows that all the three sub-watersheds have streams up to fourth order. However, due to variable sub surface conditions the number of first, second and third order streams vary considerably in the entire three sub watersheds. Further, stream order decreases with the decrease of stream number (Fig-1.8)

\section{(2)Stream length (Lsm)}

The Stream length values in all three sub-watersheds are maximum for first order streams and decreases as stream order increases. The result further validates the Horton's law which states that geometrical similarity is maintained in the basins of increasing orders. Relation between stream number and streams order is demonstrated by line graph in Fig (1.8) which shows that result are in consistency with the [11] observations.

\section{(3)Mean stream length (Lsm)}

The mean length of a channel is a dimensional property and reveals the characteristic size of drainage network components and contributing basin surface. Table [1.1 (b)] shows that the mean length in the study area ranges from 0.39 to 2.4 for all three sub-watersheds. The result also shows that a particular order is greater than that of the next order and less than that of its next higher order. Fig (1.9) shows that stream order increases with the increase of mean stream length.

\section{(4)Stream length ratio (RI)}

The stream length ratio is defined as the ratio between the lengths of streams in a given order to the total length of streams in the next lower order [11]. It has an important relationship with the surface flow discharge and erosional stage of the basin. In present investigation, sub-watershed 2 shows greatest variation in stream length ratio as it is geologically influenced due to its location at the southern extremity of Ganga basin which is bounded in the south by Peninsular shield. 


\section{IARJSET \\ Vol. 4, Issue 5, May 2017}

\section{(5)Bifurcation Ratio (Rb)}

[11] and [12] consider the bifurcation ratio as an index of relief and dissection whereas [13] express the bifurcation ratio is directly related to the risk factor of flood. The bifurcation ratio is the ratio of the number of stream segments of given order to the number of stream segments of next higher order. The bifurcation ratios of all the sub-watersheds in parts of Yamuna flood plain ranges from 4.83 to 5.34 Table-1.1 (a).The variation in $\mathrm{Rb}$ values is possibly due to environmental fluctuation and control of geological structures on the drainage basin. The subwatershed- 2 suffered the highest structural disturbance as it is located on the southern boundary of Ganga basin and bounded to the south by Peninsular shield (Vindhyan basin) which might exerts a little control over drainage pattern. The relatively high bifurcation ratio indicates a potential for flash flooding during the storm events. [14], [2].

\section{AREAL ASPECTS}

The areal aspects computed include drainage density, drainage texture stream frequency circulatory ratio and length of overland flow. The results are given in table and discussed as:-

\section{(6)Drainage Density (D)}

The drainage density is an indicator of the linear scale of landform elements and stream eroded topography defined as the total length of streams of all drainage areas and is an expression of the closeness of spacing of channels[11]. In general, the hydrology of basin changes significantly in response to the changes in the drainage density. [15] recognize the significance of drainage density as a factor determining the travel time by water. The low Drainage density is favoured in regions of highly permeable sub soil material, under dense vegetation cover where relief is low while high drainage density is favoured in regions of weak or impermeable sub surface materials, sparse vegetation and mountain relief [16]. The drainage density for the sub-watershed 1,2 and 3 are $0.76,0.46$ and 1.30 , respectively, which are comparatively low, indicates that the area is underlain by highly resistant permeable material with vegetative cover and low relief [17]. Generally, Dd values increases with decreasing infiltration capacity of the underlying rocks. The drainage density values are also related to the climate and surface runoff of the study area. Heavy rain results more runoff which at places reduced due to permeable subsurface and vegetation cover results increased infiltration.

\section{(7)Drainage frequency (Fs)}

The lesser values of drainage density and stream frequency results in the low runoff and therefore, flooding is less likely in basin and vice versa [2]. The stream frequency of sub-watersheds 1, 2 and 3 are 1.71, 0.76 and 2.29, respectively, shows that the sub watersheds 1 and 2 are less prone to flooding in comparison to sub-watershed 3 . The sub-watershed 1 and 3 are having more permeable rock beneath as compared to sub-watershed 2 .

\section{(8)Drainage Texture (Rt)}

The drainage shows the relative spacing of the drainage lines [11]. There are numerous drainage lines over impermeable areas than over permeable areas and is the measure of the total number of segments of all order per perimeter of the area, gives an idea regarding infiltration rates of the area. [17] Classified drainage texture into five different types as very coarse $(<2)$ coarse $(2-4)$ moderate $(4-6)$ fine $(6-8)$ and very fine $(>8)$. The soft or weak rocks unprotected by vegetation produce a fine texture, whereas massive and resistant rocks cause coarse texture. In the study the texture for sub-watersheds 1 and 3 are 5.20 and 5.92 respectively and 1.64 in sub-watershed 2, suggest moderate to coarse drainage texture respectively in accordance with the Smith classification [17] of drainage textures. Subwatershed 2 shows exceptionally very coarse drainage texture possibly due to its location nearest to the rocks belonging to the Vindhyan Supergroup.

\section{(9)Elongation ratio $(\mathrm{Re})$}

The elongation ratio is defined as the ratio of the diameter of a circle of the same area as that of the drainage basin and the maximum length of the basin. A circular basin seems to have more efficient discharge of runoff than an elongated basin[18]. The Re values near to 1 represent the region of low relief whereas values between 0.6 and 0.8 are found associated with steep relief and ground slope [10]. The ratio remains between 0.5 and 1.0 over a wide range of climate and geographic type. These values can be further categorized as, circular $(>0.9)$, oval (0.9-0.8) and less elongated $(<0.7)$. The elongation ratio value in the study area varies from 0.41 ; to 0.68 up to 0.69 suggest that the area has low to slightly moderate ground slope. The lowest value in case of sub-watersheds-1 indicate high relief and comparatively steep slope, whereas, sub-watersheds 2 and 3 are almost plain land (Fig 1.5, 1.6 and 1.7). Elongated basin with low form factor (Fig-2.0) indicates that the basin will have a flatter peak of flow for longer duration. Flood flows of such elongated basins appear to be easier to manage than that of the circular basins[19].

\section{(10) Circulatory ratio (Rc)}

[20] Defined circulatory ratio of the area of a basin to the area of the circle having the same circumference as the perimeter of the basin. The circulatory ratio is influenced by length and frequency of the streams, geological structures, 
land use/land cover, climate, relief and slope of the basin [21]. [11] Has given the value of Rc ratio as 0.6 to 0.7 for the homogenous geological material in order to preserve the geometric symmetry. The circulatory ratio (Rc) values of subwatershed 1 is 0.12 while sub-watersheds 2 and 3 having Rc values 0.07 and 0.06 , respectively indicate elongated to slightly elongated shape of the basin (Fig-1.5, 1.6, 1.7).

\section{(11)Infiltration ratio (If)}

Infiltration number is defined as the product of drainage density and stream frequency of the basin. The higher infiltration number indicates low infiltration and higher runoff [17]. The present study shows that the sub-watersheds 1 , 2 and 3 having the values $1.33,0.34$ and 2.9 respectively, indicates that the surface runoff is high in sub-watershed 1 and 3 as compared to sub-watershed 2.

\section{(12)Length of overland flow ( $\mathrm{Lg}$ )}

Length of overland flow is defined as the length of water over the ground before it gets concentrated into irregular stream channels [11]. Higher value of $\mathrm{Lg}$ indicates low relief and low value indicate high relief. The sub-watersheds 1 , 2 and 3 show the value of $(\mathrm{Lg})$ as $0.64,1.08$ and 0.38 , respectively. These values indicates that the sub-watershed 3 is very well drained and having low to moderate relief while sub-watersheds 1 and 2 have low runoff and depict moderate relief .The presence of Great Boundary Fault in the vicinity of Agra district further validates the assumption that geologic structure might have some control over drainage pattern.

\section{(13)Form factor (Rf)}

[11] Proposed this parameter to predict the flow intensity of the basin of definite area and define as the ratio of the basin area to the square of the basin length. Long narrow basin have larger length hence smaller form factor, whereas circular basins have intermediate and short and wide basins have largest form factors. The three sub-watersheds of the study area shows form factor values as $0.38,0.37$ and 0.13 respectively. These values are in consistent with the observed relations for basin shape and flow intensity. Shape factors of the drainage basin viz; Rf, Rc and Re are negatively correlated (Fig-2.0).

\section{RELIEF ASPECTS}

The relief aspects determined include relief ratio, relative relief and ruggedness number. The results of the analysis are given in Table (1.3).

\section{(14)Ruggedness Number (Hd)}

It is the product of maximum basin relief $(\mathrm{H})$ and drainage density $(\mathrm{Dd})$, where both parameters are in the same unit. Higher values shows uneven topography, lithological heterogeneity of terrain and high amount of dissection, moderate value indicate flat topped surface or ridge and valley topography and moderate to moderately high degree of dissection and lower values are found in areas of less dissection and levelled surface [22]. Extreme high values of ruggedness number occur when both variables are large, when slope is not only steep but long as well [23]. The present study shows that sub-watersheds 1,2 and 3 having values of ruggedness number as $0.12,0.073$ and 0.20 , respectively. These values are comparatively low and indicate homogenous lithology, and gentle slope of all the three sub-watershed.

\section{(15)Relative relief (Rhp)}

The term relative relief is defined as the ratio of maximum basin relief to the perimeter of the basin and was introduced by [24]. The relative relief of different sub-watersheds have been determined (Table-1.3).It is found that the subwatershed 1 and 2 having maximum values and sub-watershed 3 has minimum value. These results further validated with the Digital Elevation Model (DEM) (Fig-1.5, 1.6 1.7) of the study area indicate that elevation varies from 89 to 204 meter; represent that the surface has gentle to moderate slope.

\section{(16)Relief Ratio (Rr)}

The relief ratio is a measure of the overall steepness of a drainage basin and is an indicator of the intensity of erosional process operating on slope of the basin [12]. It has been observed that there is a high degree of correlation between high relief and high drainage frequency, high stream frequency and high stream channel flow which brings out high discharge in short duration [25]. The values of relief ratio for different sub-watersheds in the area varies from 0.0032 , 0.0036 and 0.0015 for sub-watershed 1,2 and 3 respectively (Table-1.3) indicate low relief and moderate to gentle slope.

\section{HYPSOMETRIC ANALYSIS}

The topography of an area produced by stream channel erosion and associated processes of weathering massmovement, and sheet runoff is extremely complex, both in the geometry of the forms themselves and the inter-relations 


\section{IARJSET

of the process which produce the forms [26]. Hypsometric analysis of all the sub-watersheds is carried out to ascertain the susceptibility to erosion and to provide measures to mitigate it. The slope of the hypsometric curve changes with the change of watershed development, which controls the erosion characteristics of watershed and indicative of cycle of erosion. The cycle of erosion is the total time required for reduction of land area to base level i.e. lowest period. The entire period of cycle of erosion can be divided into three stages viz. (old-0.3) in which the watershed is fully stabilized; equilibrium or mature stage.

These curves have been used to infer the stage of development of the drainage network and it is also a powerful tool to differentiate between tectonically active and inactive areas [27]. The curve is drawn by plotting the proportion of total basin height against the proportion of total basin area (Fig-). Convex hypsometric curve characterize young slightly eroded regions; S-shaped curves characterize moderately eroded regions; concave curve obtained in old, highly eroded regions.

\section{Hypsometric integral (HI)}

To characterize the shape of hypsometric curve for a given drainage basin is to calculate its hypsometric integral. The integral is defined as the area under the hypsometric curve. Hypsometric integral values are determined by assigning each mean elevation, minimum elevation, and maximum elevation values to each sub-watershed of the study area. These values were estimated by using the elevation relief ratio method as proposed by [28]. The expression used is given below-

\section{HI=Minimum Elevation-Minimum Elevation/Maximum Elevation-Minimum Elevation}

Theoretically hypsometric integral values ranges between 0 and 7. Mature basins of low relief, gentle slopes, gentle stream gradients and low drainage density tend to have relatively high integral values. The high values appear to be the reflection of slightly accelerated stream corrosion rates as a result of recently accelerated southward tilting of the region associated with epierogenic uplift [26]. Low values of HI indicate old and more eroded areas and evenly dissected drainage basins. High values of $\mathrm{HI}$ indicate that most of the topography is high relative to the mean sea level, such as smooth upland surface cut by deeply incised streams indicating young and less eroded areas. Hypsometric integral values in the present sub-watersheds showing the same value of 0.5 indicates basin is in old stage of its geomorphic development.

In the present study hypsometric curves (Fig-1.9) have been drawn by using Micro-DEM tool which requires DEM data as an input. This software is specially designed for practical purposes which are applicable in the geological studies. SRTM DEM data was used demarcate the hypsometric curves for different sub-watersheds in order to understand their geomorphic nature. Fig [2.0 (A), (B) and (C)] are showing very little variation, in general, the entire basin appear to be of mature to old stage of geomorphic development. Though, a lesser degree of variations has been found out by analysing the different curves. They all are interpreted as belongs to old stage, however, only subwatershed -2 [Fig 1.9 (B)] shows a little deviation from proper S-shape of the curve, and interpreted as in mature stage of geomorphic development. Hypsometric concave curves show low runoff with a higher fraction of surface response while convex basin exhibits high runoff with larger contributions from subsurface processes. Larger differences in basin hydrology would be expected for greater observed variations in the hypsometric variations, but results shows more or less similar hydrological behaviour of the all the sub watersheds in the study area.

\section{CONCLUSION}

Morphometric analysis of river basin using GIS techniques plays a vital role in hydrological and geomorphological sciences and facilitates analysis of different morphometric parameters and explores the relationship among the drainage basin morphometry and hypsometric analysis and provides holistic approach about topographical, geological, lithological, structural, pedological and hydrological aspects of the basin. The entire flood plain is of fourth order with several paleochannels and extinct tributaries which shows the scarcity of water in the flood plain.

The mean $\mathrm{Rb}$ values suggest that the basin is less geologically controlled and low Dd values indicates more or less permeable subsurface strata. The entire basin has course drainage texture (Dt) and low (If) indicates high infiltration capacity and low runoff rate. The (Rc), (Rf) and (Re) values shows that the sub-watersheds in the flood plain have more or less elongated shape and low relief of the basin. High hypsometric integral values and S-shaped (concave) hypsometric curve indicate the mature to old geomorphic stage of river development and supports the theory of up warping and corrosion of the streams (situated at the boundary of peninsular shield and Ganga basin) regarding the origin of Yamuna ravines in the study area. 
Table 1- Methodology adopted for the computation of morphometric parameters.

\begin{tabular}{|c|c|c|c|c|}
\hline S.NO. & PARAMETER & SYMBOL/FORMULA & DESCRIPTION & REFERENCE \\
\hline 1. & Stream Order & Hierarchical Rank & $\begin{array}{l}\text { Lu=Total Stream Length } \\
\text { of order } \mathrm{u} \text {. }\end{array}$ & Strahler (1964) \\
\hline 2. & Stream Length & & $\begin{array}{l}\text { Nu=Total number of } \\
\text { Stream segment of order } \\
\text { u. }\end{array}$ & Horton (1932) \\
\hline 3. & Mean Stream Length & $\mathrm{Lsm}=\mathrm{Lu} / \mathrm{Nu}$ & $\begin{array}{l}\text { Lu-1= Total Stream } \\
\text { length of its next lower } \\
\text { order. }\end{array}$ & \\
\hline 4. & Stream Length Ratio & $\mathrm{RL}=\mathrm{Lu} / \mathrm{Lu}-1$ & $\mathrm{P}=$ Perimeter & Horton (1945) \\
\hline 5. & Bifurcation Ratio & $\mathrm{Rb}=\mathrm{Nu} / \mathrm{Nu}+1$ & Dd=Drainage density & Schumm (1956) \\
\hline 6. & Mean Bifurcation Ratio & & & Schumm (1956) \\
\hline 6. & Drainage Density & $\mathrm{D}=\mathrm{Lu} / \mathrm{A}$ & $\begin{array}{l}\mathrm{Nu}+1=\text { No. of segments } \\
\text { of next higher order. }\end{array}$ & Horton (1932) \\
\hline 7. & Drainage Frequency & $\mathrm{Fs}=\mathrm{Nu} / \mathrm{A}$ & $\begin{array}{l}\mathrm{Pi}=\pi ; A=\text { Area of Basin } \\
\left(\mathrm{km}^{2}\right)\end{array}$ & Horton (1932) \\
\hline 8. & Drainage Texture & $\mathrm{Rt}=\mathrm{Nu} / \mathrm{P}$ & $\mathrm{Lb}=$ Basin Length & Smith (1950) \\
\hline 9. & Elongation Ratio & $\operatorname{Re}=(2 / \mathrm{LB})^{*}(\mathrm{~A} / \mathrm{Pi})^{0 \cdot 5}$ & $\mathrm{H}=$ Basin relief & Horton (1932) \\
\hline 10. & Circulatory Ratio & $\mathrm{Rc}=4 * \mathrm{Pi}^{*} \mathrm{~A} / \mathrm{P}^{2}$ & $\mathrm{Rt}=$ Draiange texture & Miller (1953) \\
\hline 11. & Infiltration Ratio & $\mathrm{If}=\mathrm{Rt} * \mathrm{Fs}$ & Fs=Draige frequency & \\
\hline 12. & $\begin{array}{l}\text { Length of Overland } \\
\text { Flow }\end{array}$ & $\mathrm{Lg}=1 / \mathrm{D} * 2$ & & Horton (1945) \\
\hline 13. & Form Factor & $\mathrm{Rf}=\mathrm{A} / \mathrm{Lb}^{2}$ & & Horton (1932) \\
\hline 14. & Ruggedness Number & $\mathrm{Hd}=\mathrm{H}^{*} \mathrm{Dd}$ & & Melton (1957) \\
\hline 15. & Relative Relief & $\mathrm{Rhp}=\mathrm{H}^{*} 100 / \mathrm{P}$ & & Schumm (1956) \\
\hline 16. & Relief Ratio & $\mathrm{Rr}=\mathrm{H} / \mathrm{Lb}$ & & Schumm (1956) \\
\hline
\end{tabular}

Table 1.1(a) Linear parameters for different sub-watersheds of the study area.

\begin{tabular}{|c|c|c|c|c|c|c|}
\hline \multirow[t]{2}{*}{ Stream order } & \multicolumn{2}{|c|}{ SW-1 } & \multicolumn{2}{|c|}{ SW-2 } & \multicolumn{2}{|c|}{ SW-3 } \\
\hline & $\begin{array}{l}\text { Stream } \\
\text { no. }\end{array}$ & $\begin{array}{l}\text { Bifurcation } \\
\text { ratio }(\mathbf{R b})\end{array}$ & $\begin{array}{l}\text { Stream } \\
\text { no. }\end{array}$ & $\begin{array}{l}\text { Bifurcation } \\
\text { ratio (Rb) }\end{array}$ & Stream no. & $\begin{array}{l}\text { Bifurcation ratio } \\
\text { (Rb) }\end{array}$ \\
\hline First & 1238 & 4.25 & 437 & 4.41 & 2406 & 4.43 \\
\hline Second & 291 & 4.15 & 99 & 4.95 & 542 & 4.20 \\
\hline Third & 70 & 7 & 20 & 6.66 & 129 & 5.86 \\
\hline Fourth & 10 & - & 3 & - & 22 & - \\
\hline $\begin{array}{l}\text { Mean bifurcation } \\
\text { ration }(\mathrm{Rbm})\end{array}$ & & 5.13 & & 5.34 & & 4.83 \\
\hline
\end{tabular}

Table 1.1(b) Linear parameters for different sub-watersheds of the study area

\begin{tabular}{|c|c|c|c|c|c|c|c|c|c|}
\hline & \multicolumn{3}{|c|}{ SW-1 } & \multicolumn{3}{|c|}{ SW-2 } & \multicolumn{3}{|c|}{ SW-3 } \\
\hline $\begin{array}{l}\text { Stream } \\
\text { Order }\end{array}$ & $\begin{array}{l}\text { Stream } \\
\text { length } \\
(\mathbf{K m})\end{array}$ & $\begin{array}{l}\text { Mean } \\
\text { Stream } \\
\text { Length } \\
(\mathbf{L s m}) \\
(\mathbf{K m})\end{array}$ & $\begin{array}{l}\text { Stream } \\
\text { Length } \\
\text { Ratio } \\
\text { (RL) }\end{array}$ & $\begin{array}{l}\text { Stream } \\
\text { Length } \\
(\mathbf{K m})\end{array}$ & $\begin{array}{l}\text { Mean } \\
\text { Stream } \\
\text { Length } \\
(\mathbf{L s m}) \\
(\mathbf{K m})\end{array}$ & $\begin{array}{l}\text { Stream } \\
\text { Length } \\
\text { Ratio } \\
\text { (RL) }\end{array}$ & $\begin{array}{l}\text { Stream } \\
\text { Length } \\
(\mathbf{K m})\end{array}$ & $\begin{array}{l}\text { Mean } \\
\text { Stream } \\
\text { Length } \\
\text { (Lsm) }\end{array}$ & $\begin{array}{l}\text { Stream } \\
\text { Length } \\
\text { Ratio } \\
\text { (RL) }\end{array}$ \\
\hline First & 483.457 & 0.39 & 0.35 & 221.235 & 0.50 & 3.05 & 1166.310 & 0.48 & 0.32 \\
\hline Second & 170.417 & 0.58 & 0.36 & 72.527 & 0.73 & 1.91 & 382.335 & 0.70 & 0.42 \\
\hline Third & 61.710 & 0.88 & 0.28 & 37.885 & 1.8 & 5.06 & 163.282 & 1.26 & 0.31 \\
\hline Fourth & 17.825 & 1.7 & - & 7.481 & 2.4 & - & 51.544 & 2.34 & - \\
\hline
\end{tabular}


Table 1.1(c) Linear parameters for different sub-watersheds of the study area.

\begin{tabular}{|c|c|c|c|c|c|c|}
\hline $\begin{array}{l}\text { S. } \\
\text { NO. }\end{array}$ & $\begin{array}{l}\text { Name of the } \\
\text { Catchment }\end{array}$ & $\begin{array}{l}\text { Drainage } \\
\text { Density (Dd) }\end{array}$ & $\begin{array}{l}\text { Stream } \\
\text { Frequency (Fs) }\end{array}$ & $\begin{array}{l}\text { Infiltration } \\
\text { Number } \\
\text { (If) }\end{array}$ & $\begin{array}{l}\text { Drainage } \\
\text { Texture } \\
\text { (Rt) }\end{array}$ & $\begin{array}{l}\text { Length of overland } \\
\text { Flow (Lg) }\end{array}$ \\
\hline 1. & SW-1 & 0.78 & 1.71 & 1.33 & 5.20 & 0.64 \\
\hline 2. & SW-2 & 0.46 & 0.76 & 0.34 & 1.64 & 1.08 \\
\hline 3. & SW-3 & 1.30 & 2.29 & 2.9 & 5.92 & 0.38 \\
\hline
\end{tabular}

Table 1.2 Areal parameters for different sub-watersheds of the study area.

\begin{tabular}{|llllllll|} 
S.NO. & $\begin{array}{l}\text { Name of the } \\
\text { catchments }\end{array}$ & $\begin{array}{l}\text { Area } \\
(\mathbf{A u}) \\
\left(\mathbf{k m}^{2}\right)\end{array}$ & $\begin{array}{l}\text { Maximum } \\
\text { Basin Length } \\
(\mathbf{L b})(\mathbf{K m})\end{array}$ & $\begin{array}{l}\text { Basin } \\
\text { Perimeter } \\
(\mathbf{P})(\mathbf{K m})\end{array}$ & $\begin{array}{l}\text { Elongation } \\
\text { Ratio } \\
(\mathbf{R e})\end{array}$ & $\begin{array}{l}\text { Circulatory } \\
\text { Ratio } \\
(\mathbf{R c})\end{array}$ & $\begin{array}{l}\text { Form } \\
\text { Factor } \\
(\mathbf{R f})\end{array}$ \\
\hline 1. & SW-1 & 939.83 & 49.56 & 308.88 & 0.41 & 0.12 & 0.38 \\
\hline 2. & SW-2 & 728.56 & 44.18 & 339 & 0.68 & 0.07 & 0.37 \\
\hline 3. & SW-3 & 1351.9 & 100.85 & 523 & 0.69 & 0.06 & 0.13 \\
\hline
\end{tabular}

Table 1.3 Relief parameters for different sub-watersheds of the study area.

\begin{tabular}{|lllll|}
$\begin{array}{l}\text { Name of the } \\
\text { Catchment }\end{array}$ & $\begin{array}{c}\text { Max. Basin Relief } \\
(\mathbf{K m})\end{array}$ & Relief Ratio & $\begin{array}{c}\text { Relative Relief } \\
(\text { Rhp) }\end{array}$ & $\begin{array}{l}\text { Ruggedness } \\
\text { Number (Hd) }\end{array}$ \\
\hline SW-1 & 0.16 & 0.0032 & 0.051 & 0.12 \\
\hline SW-2 & 0.16 & 0.0036 & 0.047 & 0.073 \\
\hline SW-3 & 0.16 & 0.0015 & 0.030 & 0.20 \\
\hline
\end{tabular}

Table 1.4 Elevation and hypsometric parameters of all the sub-watersheds.

\begin{tabular}{|rrrrrr|}
\hline Sub-watersheds & Area $(\mathrm{km})$ & Minimum elevation & Maximum elevation & Mean elevation & HI \\
\hline SW-1 & 939.83 & 89 & 204 & 146.5 & 0.5 \\
\hline SW-2 & 728.56 & 117 & 195 & 156 & 0.5 \\
\hline SW-3 & 1351.9 & 100 & 191 & 145.5 & 0.5 \\
\hline
\end{tabular}

\section{REFERENCES}

[1] E. Rodrigues and V. M. Bacani, "Morphometric Characterization of a Watershed through SRTM Data and Geoprocessing Technique," no. April, pp. 238-247, 2016.

[2] T. A. Kanth and Z. Hassan, "Mophometic analysis and prioritization of watersheds for soil and water resoruce management in Wular catchment using geo-spatial tools," Int. J. Geol. Earth Environ. Sci., vol. 2, no. 1, pp. 30-41, 2012.

[3] V. J. Markose, A. C. Dinesh, and K. S. Jayappa, "Quantitative analysis of morphometric parameters of Kali River basin, southern India, using bearing azimuth and drainage (bAd) calculator and GIS," Environ. earth Sci., vol. 72, no. 8, pp. 2887-2903, 2014.

[4] D. P. Patel, C. A. Gajjar, and P. K. Srivastava, "Prioritization of Malesari mini-watersheds through morphometric analysis: a remote sensing and GIS perspective," Environ. earth Sci., vol. 69, no. 8, pp. 2643-2656, 2013.

[5] Z. R. Ansari, L. A. K. Rao, and A. Yusuf, "GIS based morphometric analysis of Yamuna drainage network in parts of Fatehabad area of Agra district, Uttar Pradesh,” J. Geol. Soc. India, vol. 79, no. 5, pp. 505-514, 2012.

[6] T. G. Farr and M. Kobrick, "Shuttle Radar Topography Mission produces a wealth of data," Eos, Trans. Am. Geophys. Union, vol. 81, no. 48, pp. 583-585, 2000.

[7] B. Smith and D. Sandwell, "Accuracy and resolution of shuttle radar topography mission data," Geophys. Res. Lett., vol. 30, no. 9, 2003.

[8] C. H. Grohmann, "Morphometric analysis in geographic information systems: applications of free software GRASS and R," Comput. Geosci., vol. 30 , no. 9 , pp. 1055-1067, 2004.

[9] C. H. Grohmann, C. Riccomini, and F. M. Alves, "SRTM-based morphotectonic analysis of the Poços de Caldas Alkaline Massif, southeastern Brazil," Comput. Geosci., vol. 33, no. 1, pp. 10-19, 2007.

[10] A. N. Strahler, "Quantitative geomorphology of drainage basin and channel networks," Handb. Appl. Hydrol., 1964.

[11] R. E. Horton, "Erosional development of streams and their drainage basins; hydrophysical approach to quantitative morphology," Geol. Soc. Am. Bull., vol. 56, no. 3, pp. 275-370, 1945. 
[12] S. A. Schumm, "Evolution of drainage systems and slopes in badlands at Perth Amboy, New Jersey," Geol. Soc. Am. Bull., vol. 67, no. 5, pp. $597-646,1956$

[13] D. Waugh, T. Bushell, and J. Smith, Key geography foundations. Nelson Thornes, 1996.

[14] K. Rakesh, A. K. Lohani, K. Sanjay, C. Chattered, and R. K. Nema, "GIS based morphometric analysis of Ajay river basin upto Srarath gauging site of South Bihar," J. Appl. Hydrol., vol. 14, no. 4, pp. 45-54, 2000.

[15] W. B. Langbein, Topographic characteristics of drainage basins. US Government Printing Office USA, 1947.

[16] V. Te Chow, "Handbook of applied hydrology," 1964.

[17] K. G. Smith, "Standards for grading texture of erosional topography," Am. J. Sci., vol. 248, no. 9, pp. 655-668, 1950.

[18] S. Singh and M. C. Singh, "Morphometric analysis of Kanhar river basin," Natl. Geogr. J. India, vol. 43, no. 1, pp. 31-43, 1997.

[19] O. Christopher, A. O. Idowu, and A. S. Olugbenga, "Hydrological analysis of Onitsha north east drainage basin using geoinformatic techniques," World Appl. Sci. J., vol. 11, no. 10, pp. 1297-1302, 2010.

[20] V. C. Miller, "A QUANTITATIVE GEOMORPHIC STUDY OF DRAINAGE BASIN CHARACTERISTICS IN THE CLINCH MOUNTAIN AREA VIRGINIA AND TENNESSEE.," DTIC Document, 1953.

[21] R. Chopra, R. D. Dhiman, and P. K. Sharma, "Morphometric analysis of sub-watersheds in Gurdaspur district, Punjab using remote sensing and GIS techniques," J. Indian Soc. Remote Sens., vol. 33, no. 4, pp. 531-539, 2005.

[22] S. F. R. Khadri and G. V Pradhan, "Water Resource Management of Gadga River Basin, Chikhaldhara Region, Amravati District, Maharashtra with Reference to Remote Sensing Analysis."

[23] A. N. Strahler, "Dimensional analysis applied to fluvially eroded landforms," Geol. Soc. Am. Bull., vol. 69, no. 3, pp. 279-300, 1958.

[24] M. A. Melton, "An analysis of the relations among elements of climate, surface properties, and geomorphology," DTIC Document, 1957.

[25] S. N. Ramaiah, G. S. Gopalakrishna, S. S. Vittala, and K. M. Najeeb, "Morphometric analysis of sub-basins in and around Malur Taluk, Kolar District, Karnataka using remote sensing and GIS Techniques," Nature, Environ. Pollut. Technol., vol. 11, no. 1, pp. 89-94, 2012.

[26] A. N. Strahler, "Hypsometric (Area - Altitude) Analysis of Erosional Topography," Geol. Soc. Am. Bull., vol. 63, no. 11, pp. 1117-1142, 1952.

[27] E. Miccadei, T. Piacentini, F. Gerbasi, and F. Daverio, "Morphotectonic map of the Osento River basin (Abruzzo, Italy), scale 1: 30,000," J. Maps, vol. 8, no. 1, pp. 62-73, 2012.

[28] R. J. Pike and S. E. Wilson, "Elevation-relief ratio, hypsometric integral, and geomorphic area-altitude analysis," Geol. Soc. Am. Bull., vol. 82, no. 4, pp. 1079-1084, 1971

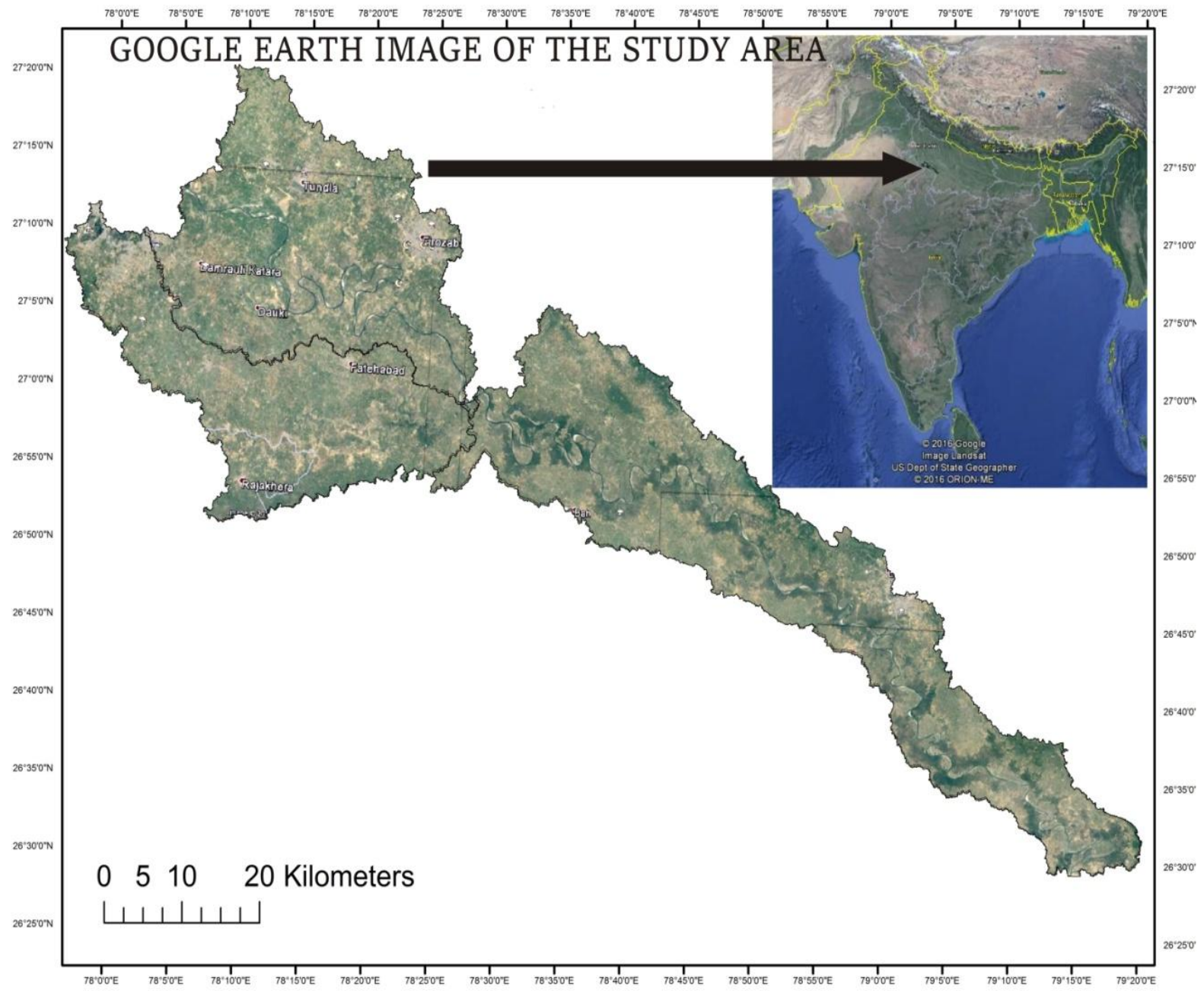

Figure 1 location map of the study area in parts of Agra, Firozabad and Etawah district along Yamuna River. 


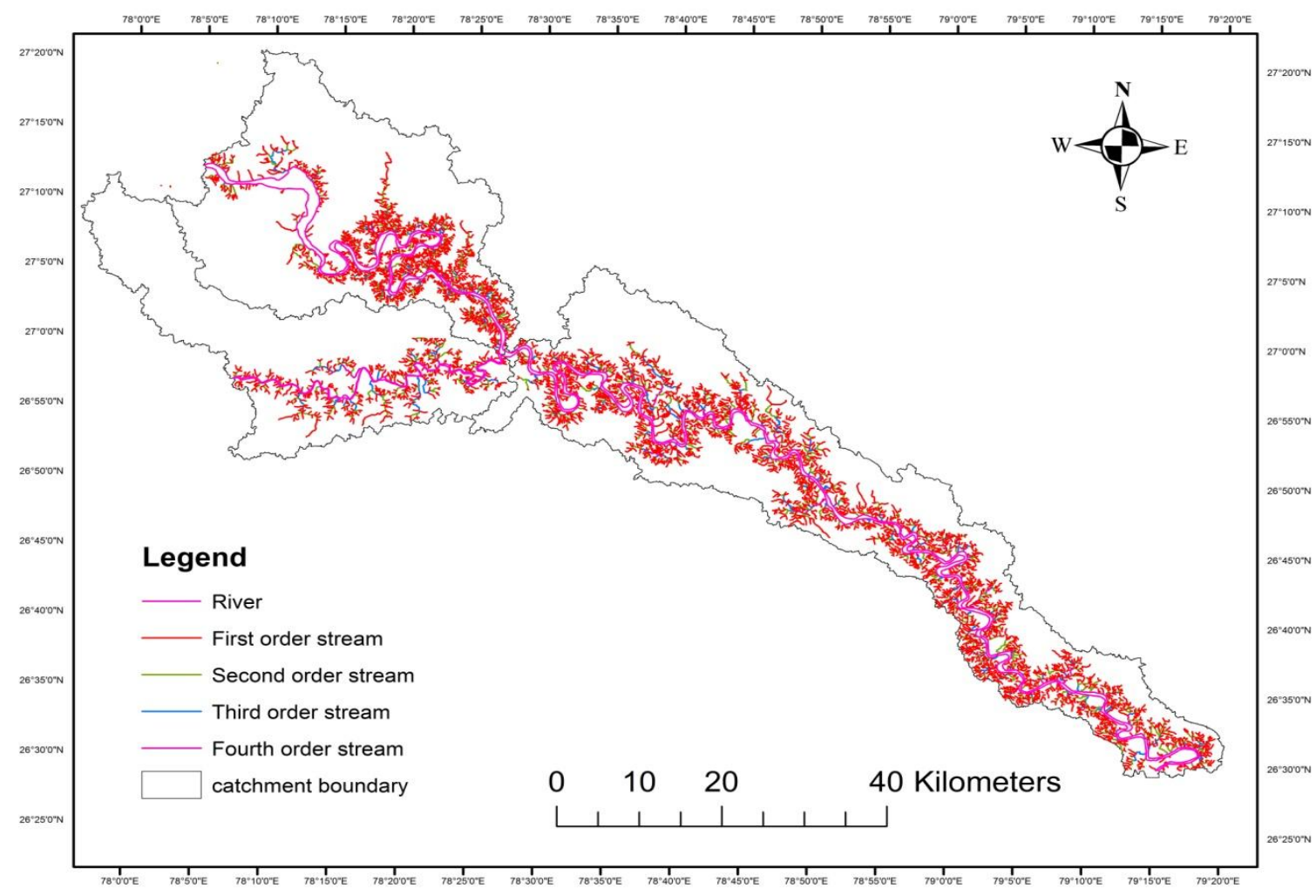

Figure 1.1 Drainage map of the study area.

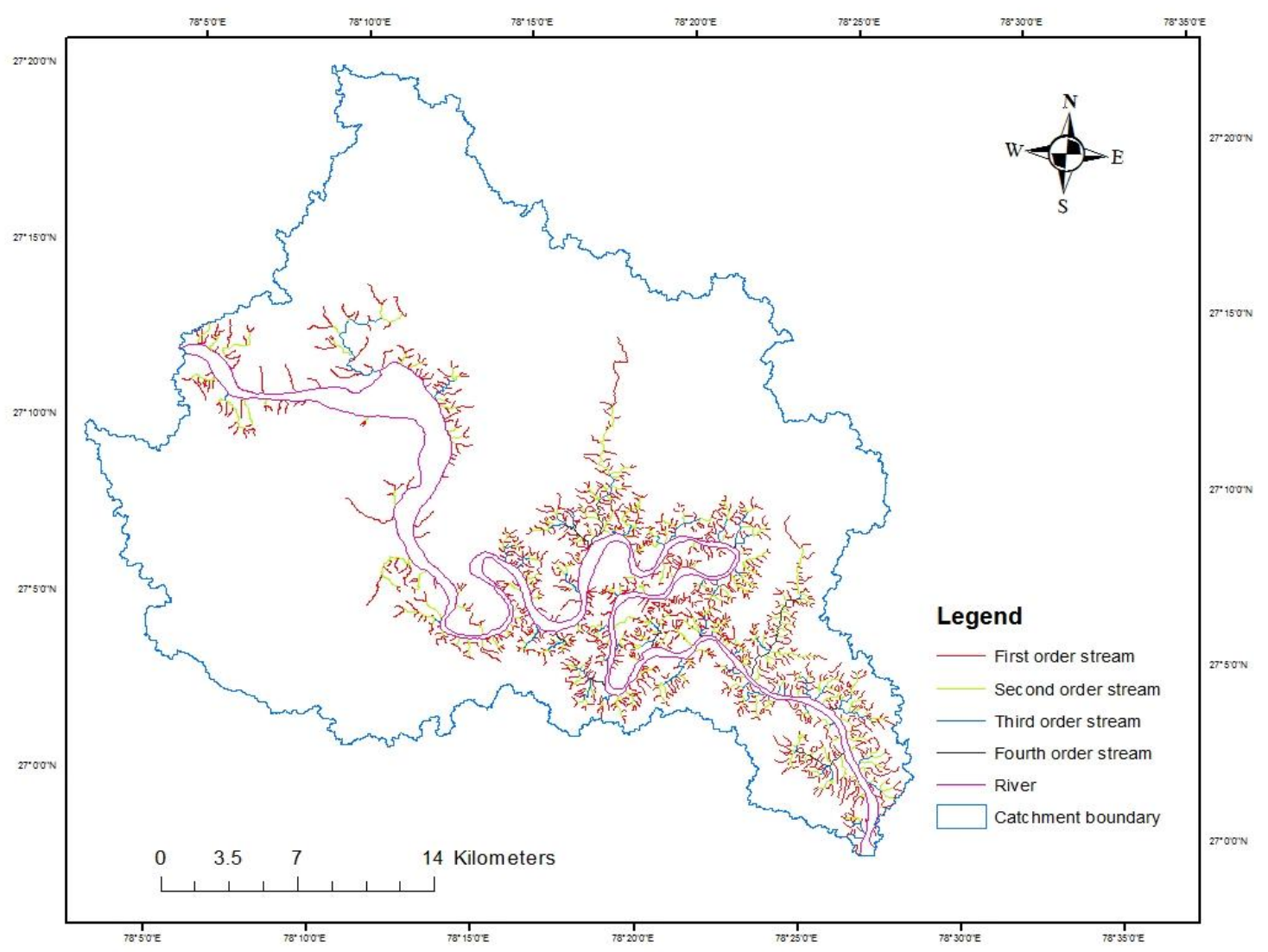

Figure 1.2 Drainage map of SW-1. 


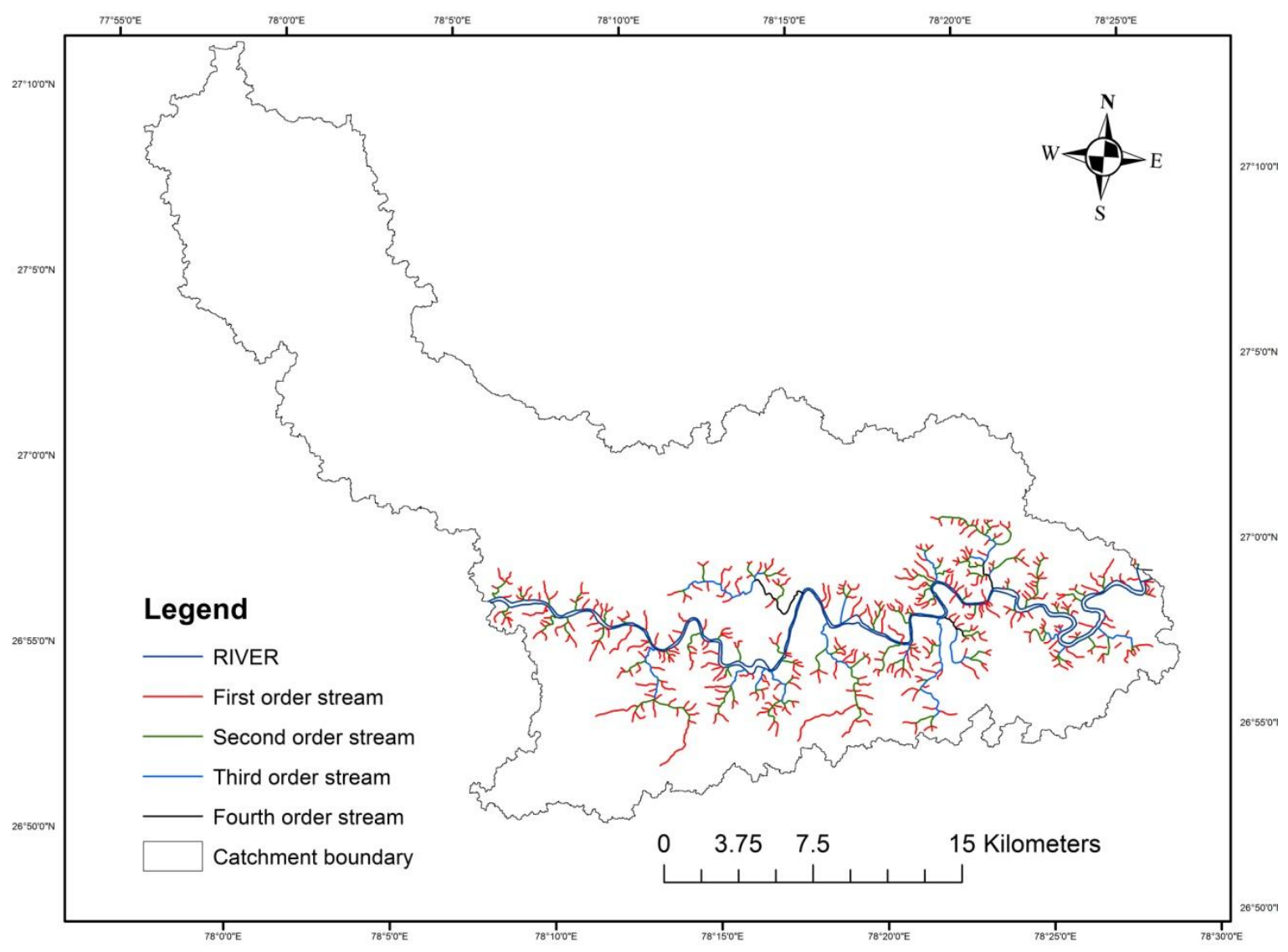

Figure 1.3 Drainage map of SW-2.

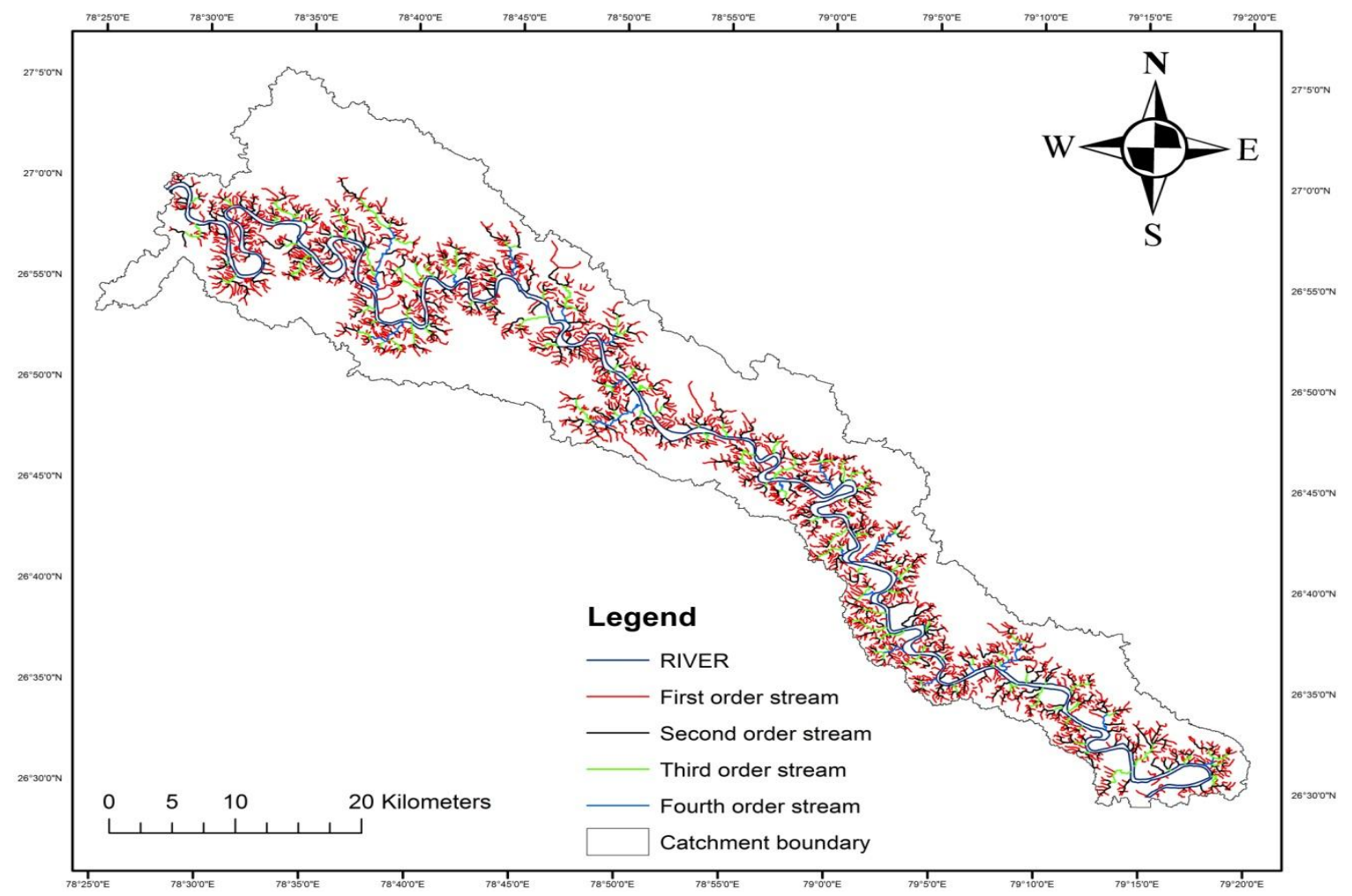

Figure 1.4 Drainage map of SW-3. 


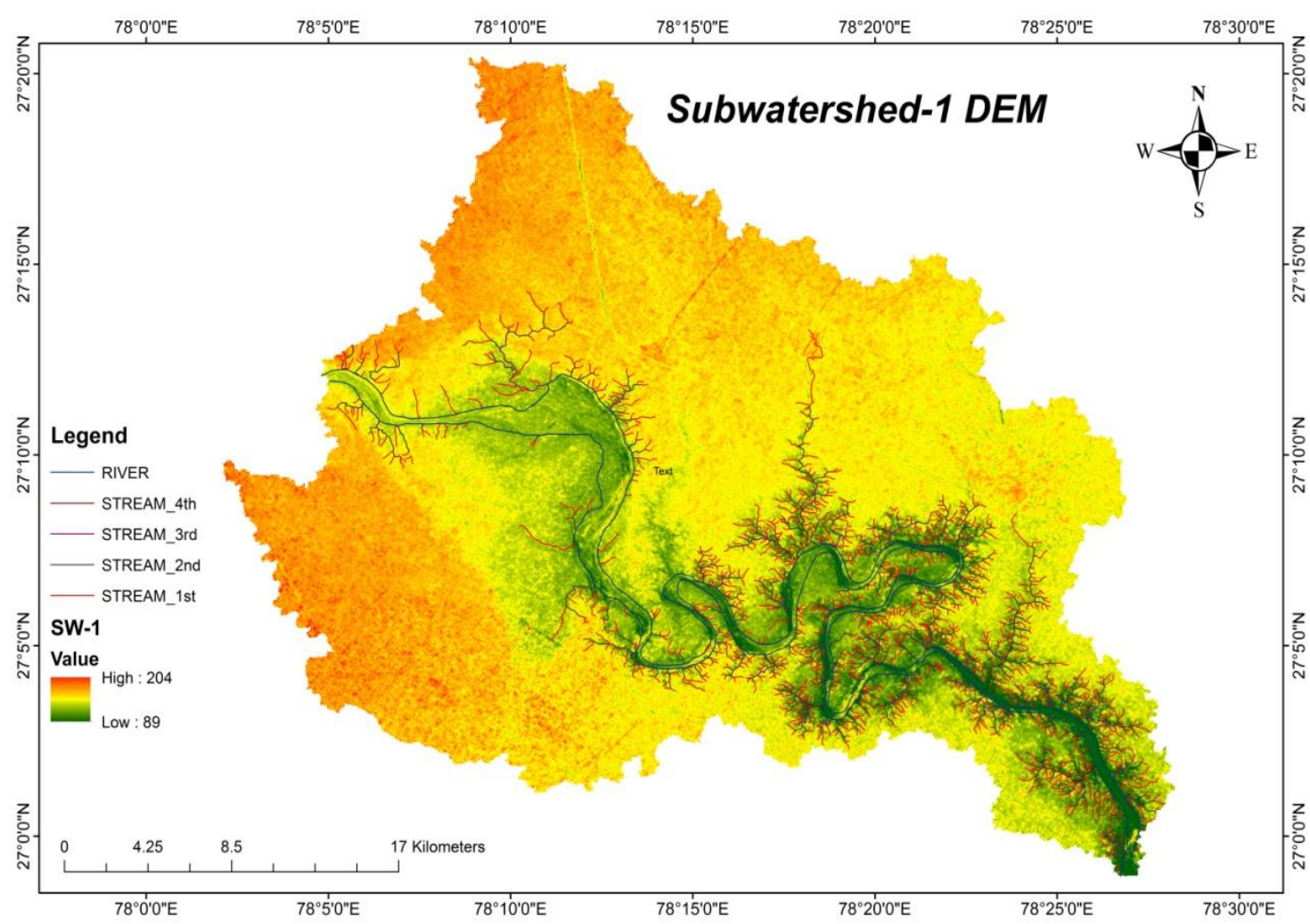

Figure 1.5 SRTM DEM for subwatershed-1 with manually extracted drainage features.

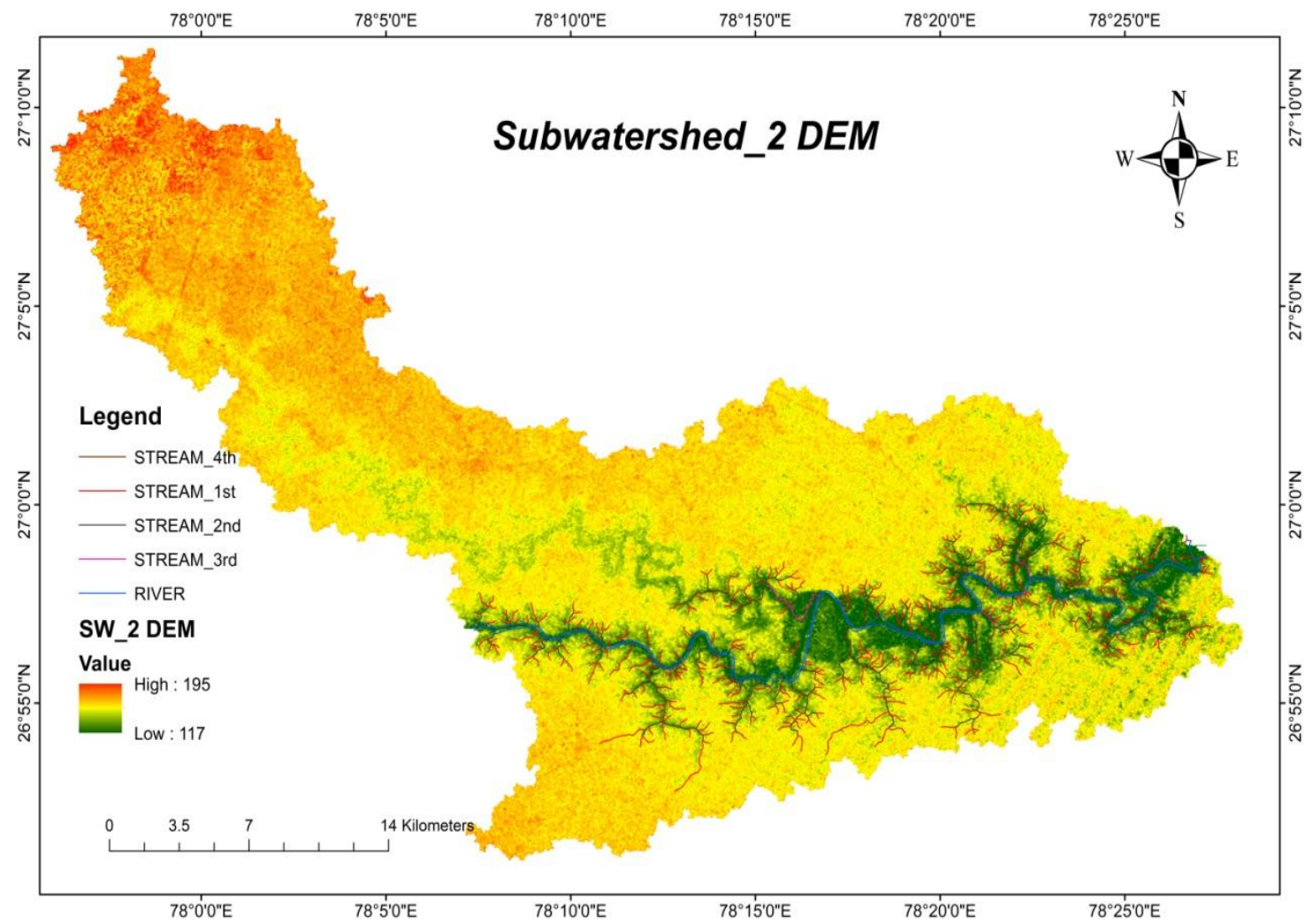

Figure 1.6 SRTM DEM for subwatershed-2 with manually extracted drainage features. 
International Advanced Research Journal in Science, Engineering and Technology ISO 3297:2007 Certified

Vol. 4, Issue 5, May 2017

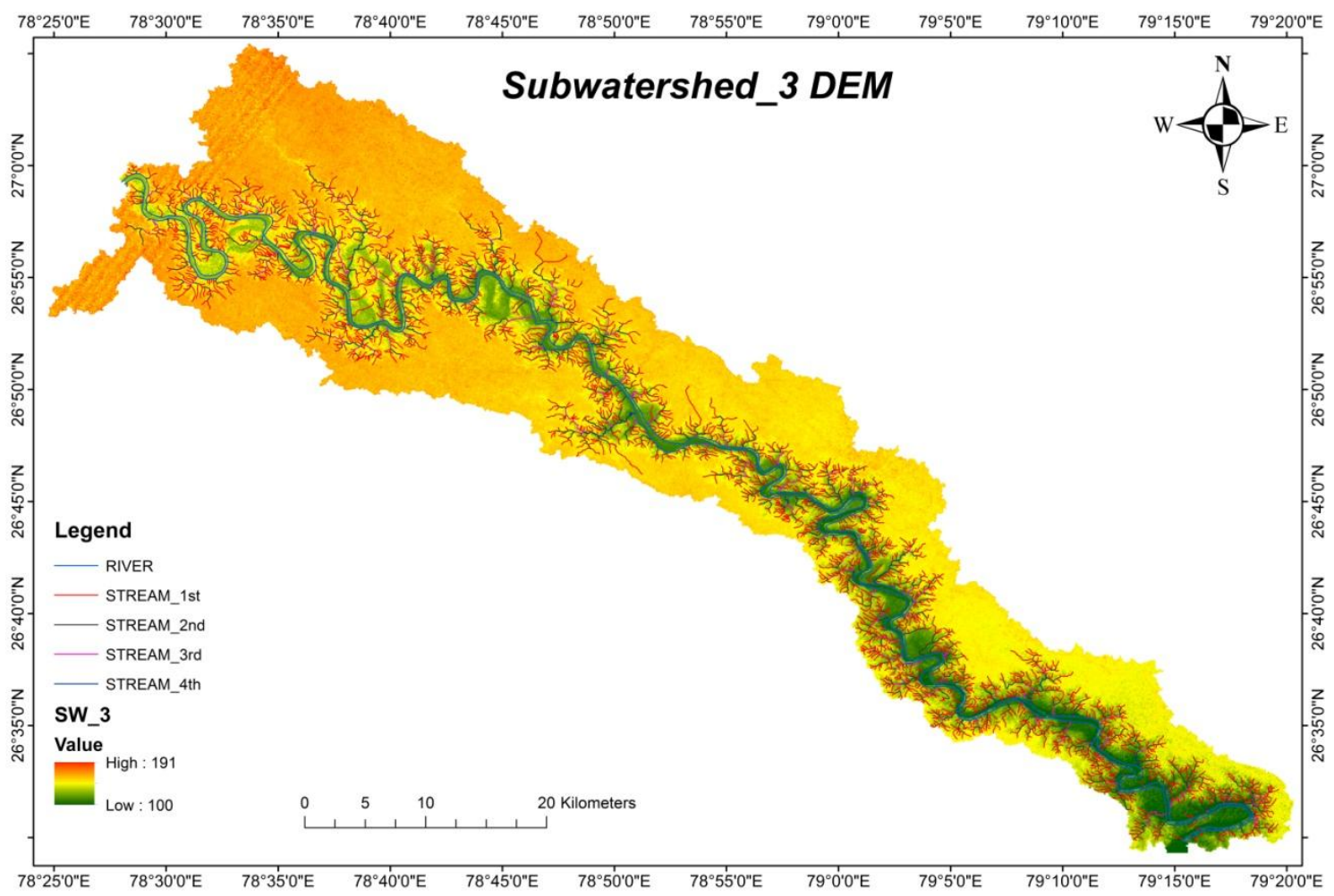

Figure 1.7 SRTM DEM for subwatershed-3 with manually extracted drainage features.

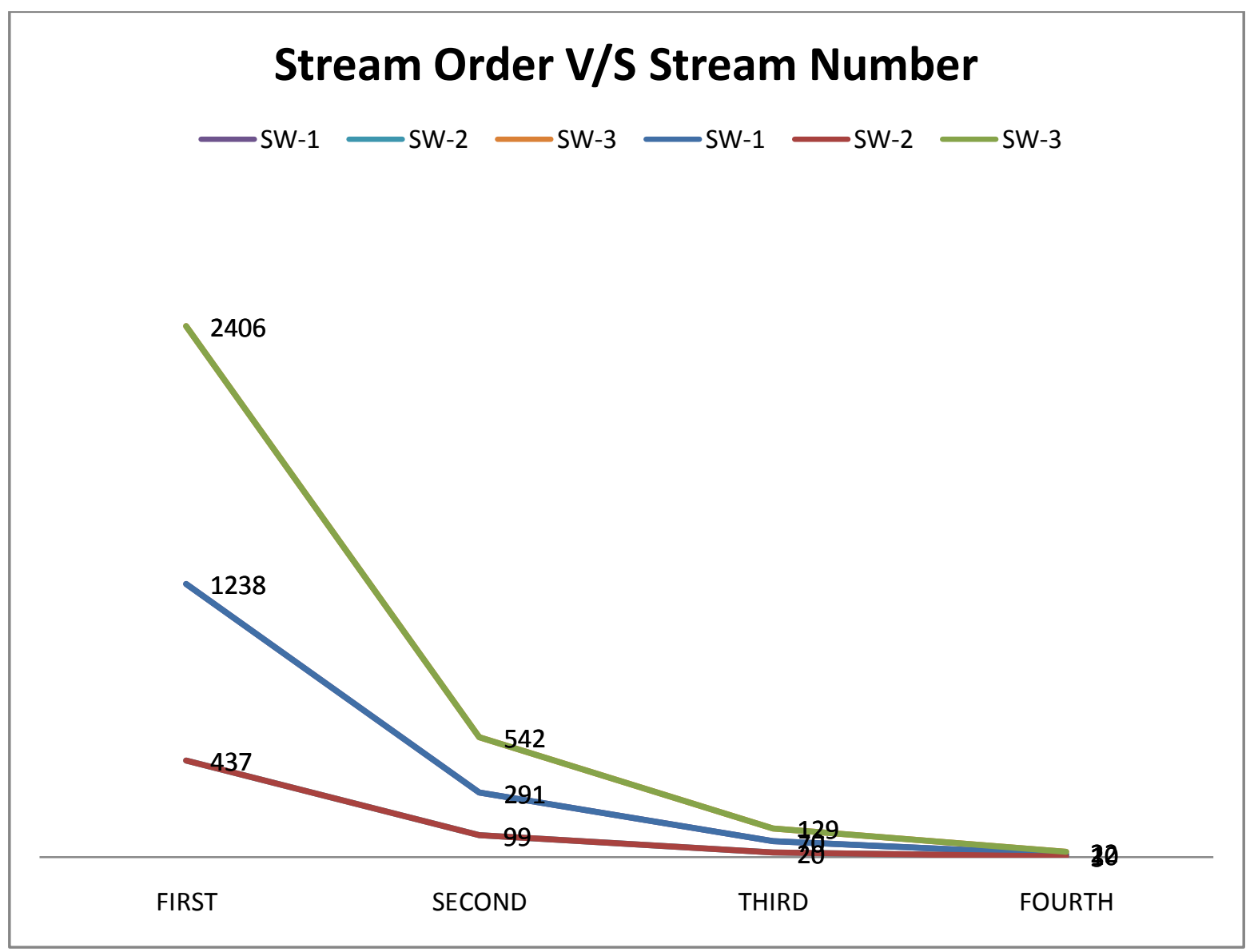

Figure 1.8 Stream order versus stream number plot for all the sub-watersheds. 


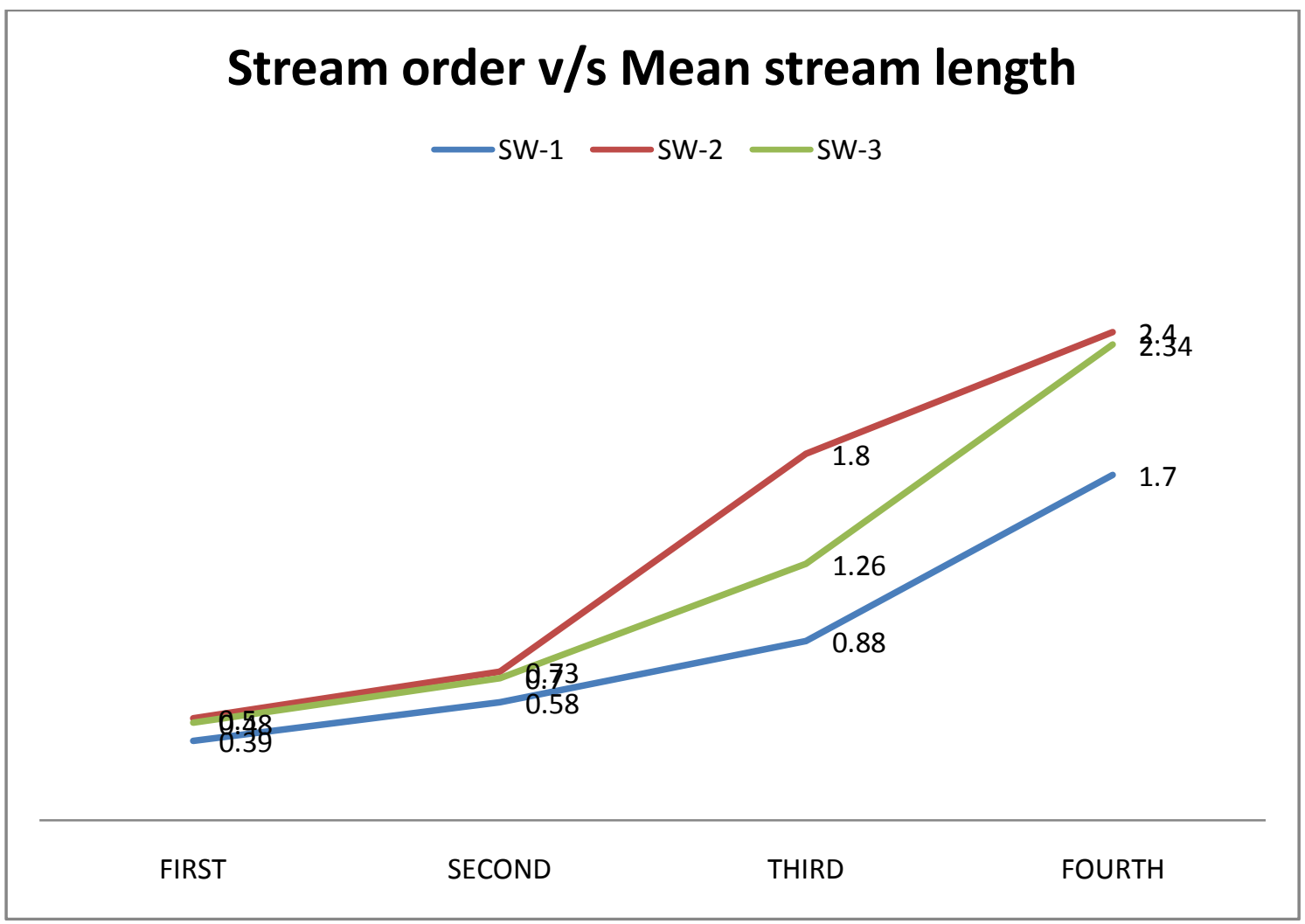

Figure 1.9 Stream order versus mean stream length plot for all the sub-watersheds.

\section{Shape Parameters}

- Form Factor Circulatory ratio Elongation Ratio

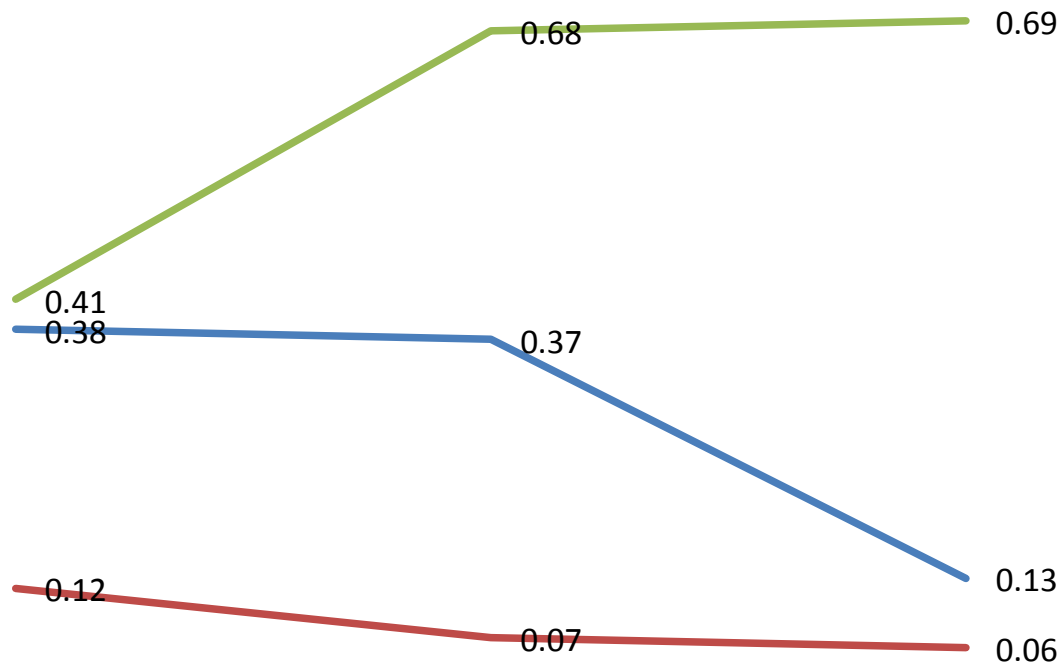

SW-1

SW-2

SW-3

Figure 2.0 Shape factor plot for all the sub-watersheds including $\mathrm{Re}$, Rc and Re. 


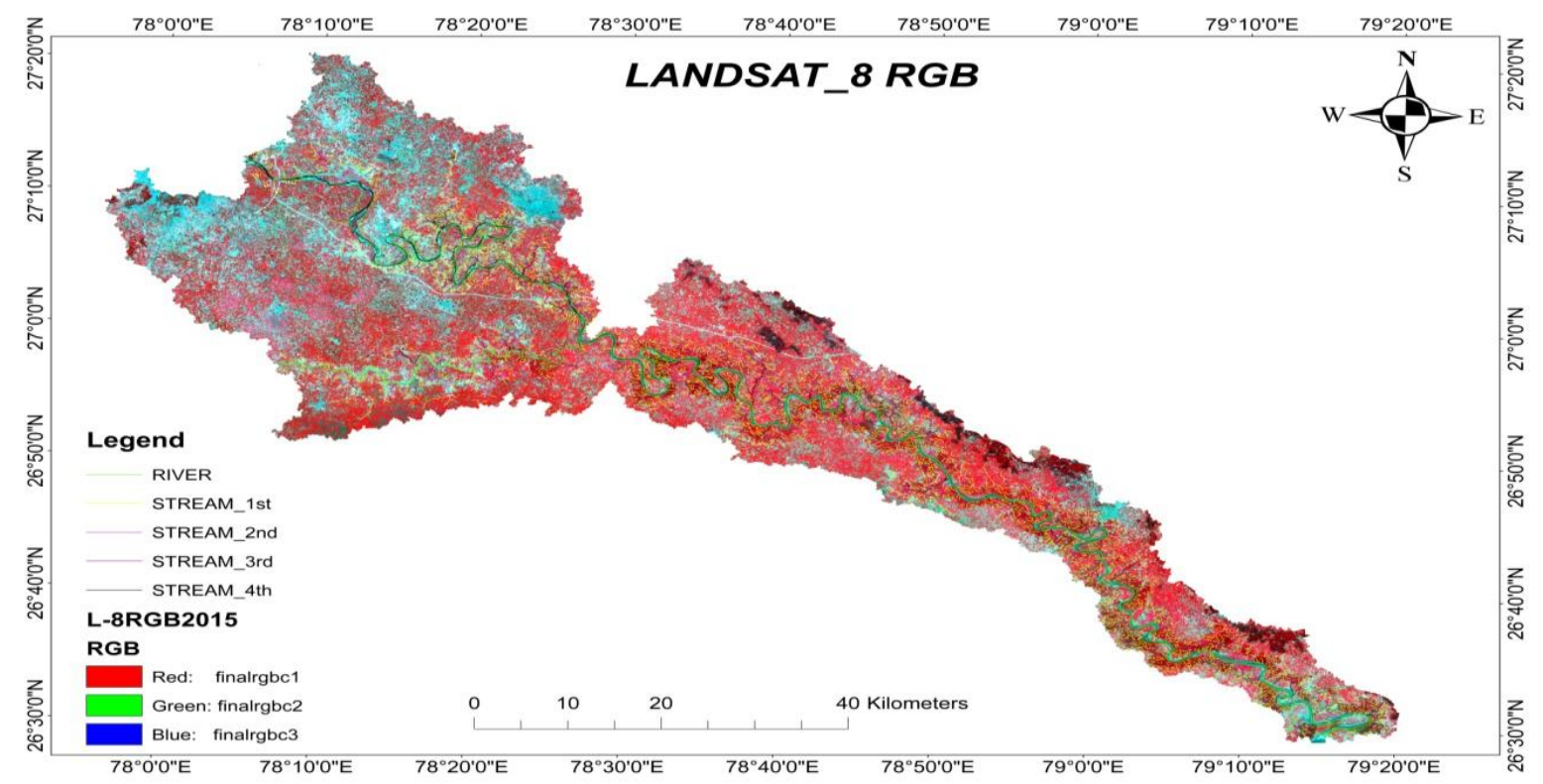

Figure 2.1 Landsat-8 (2016), Red, Green and Blue (RGB) image of the study area.

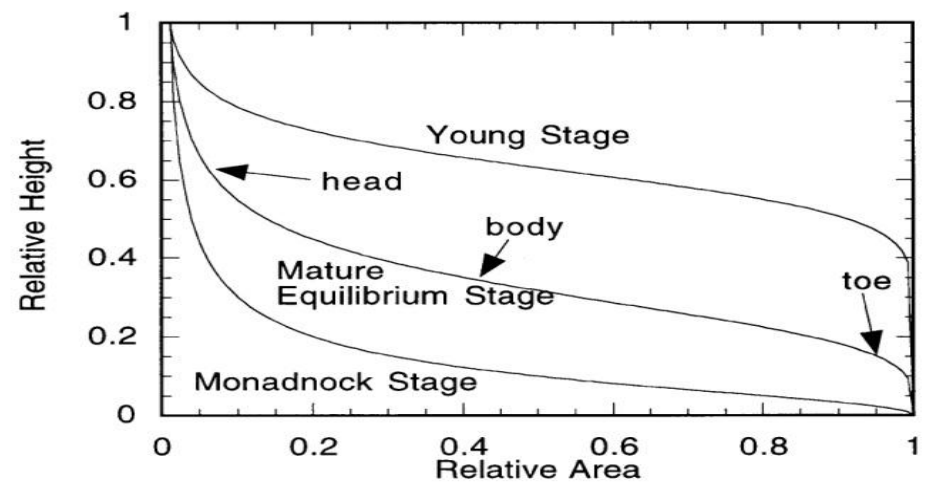

Figure 2.2 Hypsometric curve classification (after Strahler, 1964)
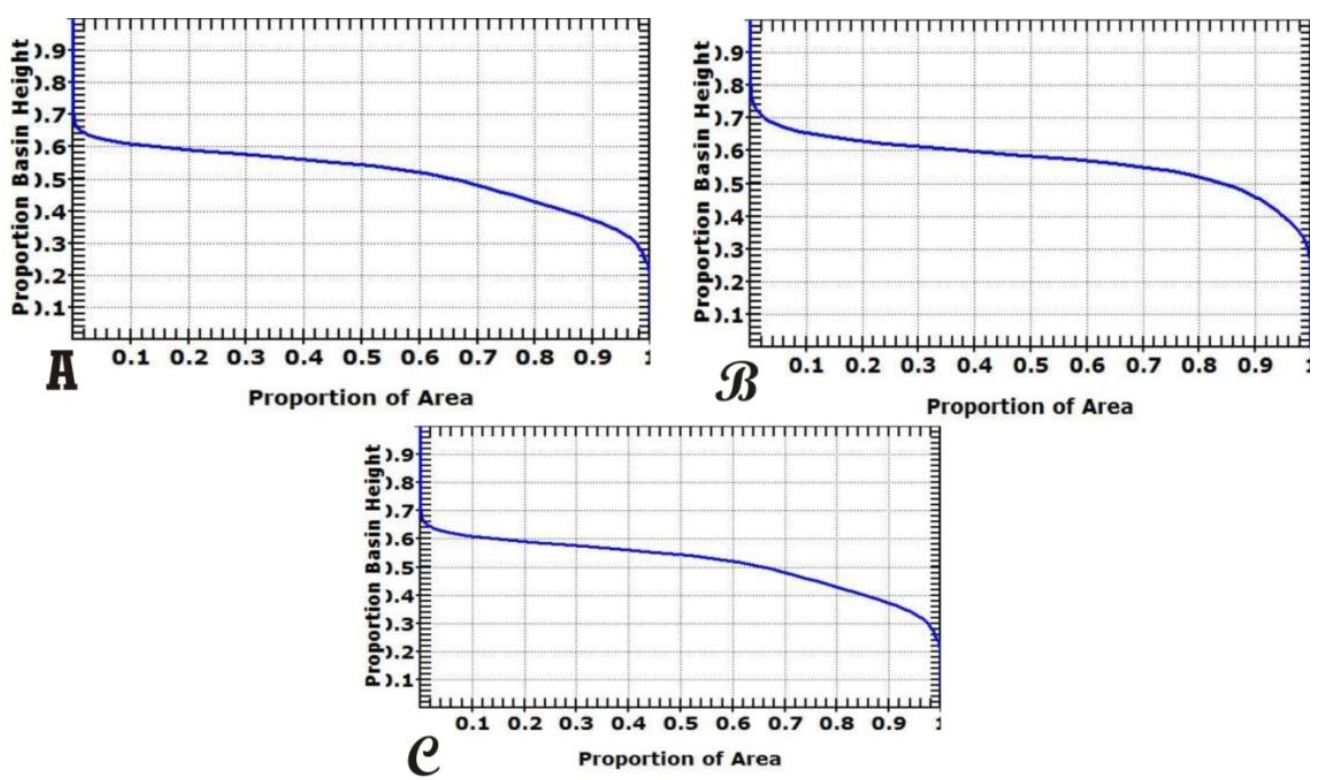

Figure shows hypsometric curves A, B and C for sub-watersheds 1,2 and 3 respectively.

Figure 2.3 Hypsometric curves for different sub-watersheds prepared by SRTM DEM. 